УДК 37.0:17.035.1](100+477)(091)

UDC 37.0:17.035.1](100+477)(091)

DOI: 10.31475/ped.dys.2018.25.06

КАТЕРИНА СТОЙКО, аспірант

(Украӥна, Тернопіль, Тернопільський національний педагогічний університет ілені Володилира Гнатюка,вул. М. Кривоноса, 2)

KATERYNA STOIKO, postgraduate student

(Ukraine, Ternopil, Ternopil Volodymyr Hnatiuk National Pedagogical University, M. Kryvonosa Str., 2)

ORCID: 0000-0002-7057-2923

\title{
Проблема альтруїзму в світовій та українській педагогіці: історичний аспект
}

\section{The Problem of Altruism in the World and Ukrainian Pedagogy: the Historical Aspect}

Основний зміст дослідження полягає у короткому ретроспективнолу тлумаченні психологопедагогічної категорії "альтруїзм»,ї̈ аналізі та розгляді у педагогічній спадщині відомих украйнських та зарубіжних науковців минулого та сучасності. Альтруӥзм характеризуе певні особливості особистості, а також являеться иіннісною якістю для життя людини. У статті представлено різноманітні дулки провідних педагогів про значення та роль альтруїзму у процесі становлення індивідуальності. Зважаючи на особливості соціальних реалій зазначених історичних епох, здійснено аналіз проблели виховання альтруїстичних якостей,короткий огляд історико-педагогічної літератури, творчої спадщини видатних представників зарубіжної та вітчизняної педагогічної дулки, а також їх практичних рекомендацій до вирішення проблеми виховання альтруїстичних якостей особистості. Представлено рівень та актуальність досліджуваної проблеми на сучасному етапі, а також ї̈ зв'язок між минулим та сьогоденнял.

Ключові слова: альтруїзм, альтруїстична поведінка, виховний ідеал, гуланізм, моральноетичний приниип, альтернативний альтруїзл.

The article deals with the phenomenon of altruism from the point of view of pedagogy which consists of the fundamental understanding of it as an important personal quality. In this case, proposed the designation "altruism" is understood like an ethic principle and moral practice of concern for the happiness of other human beings, resulting in a quality of life both material and spiritual. The concept has a long history in philosophical and ethical thought. The term was originally coined in the 19th century by the founding sociologist and philosopher of science, August Comte. Category altruism was reflected in pedagogical science. Altruism is an ethical doctrine that holds that the moral value of an individual's actions depend solely on the impact on other individuals, regardless of the consequences on the individual itself. Altruism focuses on a motivation to help others or a want to do well without reward. While ideas about altruism from one field can have an impact on the other fields, the different methods and focuses of these fields lead to different perspectives on altruism.

The investigation presents different views on the interpretation and understanding of the problem of altruism and its importance in the educational process. The preconditions of entering the category of altruism in the world and domestic pedagogical thought are considered. The above-mentioned problem has been investigated in the historical aspect.

The article proposes various ideas of leading teachers about the significance and role of altruism in the process of becoming an individual. In order to peculiarities of social realities of the mentioned historical epochs, we made the analysis of the problem of education of personality altruistic qualities based on a brief overview of historical and pedagogical literature.

The generalization of the creative heritage of prominent representatives of foreign and domestic pedagogical thought, as well as their practical recommendations to the solution of the problem of education of altruistic qualities of an individual are made. The urgency of consideration of a problem at the present stage of educational work of pupils is considered.

Key words: altruism, altruistic behavior, educational ideal, humanism, alternative altruism. 
Вступ / Introduction. Розвиток суспільства, трансформації та перетворення в освітньому просторі, необхідність реформування освіти в Україні, спрямованої на інтеграцію в европейський культурний простір, зумовлюють сучасну педагогічну науку до постійного переосмислення процесу виховання підростаючого покоління. Перед теорією та практикою освітнього процесу стоїть завдання створення умов для забезпечення гармонійного розвитку особистості як індивіда та члена суспільства, виконання якого можливе лише за умови оріентації на гуманістичні цінності. Сучасна освіта та процес виховання зокрема, мають бути зосереджені на відтворенні у підростаючому поколінні соціальної, національної і світової культур, формуванні ціннісної системи, що трунтуеться на загальнолюдських та загальнокультурних цінностях. Вчителю нової української школи, виховуючи високоморального громадянина европейської держави, необхідно орієнтуватися на виховний ідеал - особливе уявлення про те, якою повинна бути людина (Г. Ващенко, К. Ушинський). Варто зазначити, що саме виховний ідеал, втілений у традиціях та народній педагогіці, являеться основним оріентиром у системі виховання будь-якого народу.

Великий класик української педагогіки К. Ушинський зазначає: « $€$ одна тільки спільна для всіх природжена схильність, на яку завжди може розраховувати виховання: це те, що ми називаемо народністю. Виховання, створене самим народом і засноване на народних засадах, мае ту виховну силу, якої немае в найкращих системах, заснованих на абстрактних ідеях або запозичених в іншого народу »( Ушинський К., 2005).

Попри прагнення бути частиною великого европейського культурно-освітнього простору, необхідно завжди цінувати та розвивати свою власну ідентичність та самобутність, і наявність здатності до альтруїзму е одніею з важливих характеристик, притаманних традиціям формування особистості в українській педагогіці.

Мета та завдання / Aim and Tasks полягають у дослідженні проблеми альтруїзму в педагогічній думщі різних історичних епох; тлумаченні категорії альтруїзму в працях та надбаннях видатних постатей української та зарубіжної педагогічної науки; систематизації теоретичних аспектів проблеми для творчого переосмислення здобутків у сучасних умовах.

Методи / Methods. У процесі наукового пошуку використовувалися методи дослідження: загальнонаукові (аналіз, порівняння, систематизація) для узагальнення матеріалів, виявлення та систематизації науково-педагогічних ідей щодо значення та ролі альтруїзму в педагогічній діяльності, порівняльно-історичний, що дозволив простежити та зіставити думки, погляди науковців щодо означеної проблеми, герменевтичний, котрий дав можливість тлумачити та інтерпретувати тексти педагогічного, філософського спрямування.

Результати / Results. В науку термін «альтруїзм» був введений представником фiлософії позитивізму Огюстом Контом. На думку філософа, ідеальний устрій суспільства полягає у прагненні жити заради інших, а суть людського буття - служіння людству і як результат самовдосконалення. Безумовно, явище альтруїзму, поряд із іншими моральними якостями, притаманними для українського народу, знайшло свое відображення і у педагогічній науці, що розглядае його як систему ціннісних орієнтацій, спрямованих на задоволення потреб та прагнень іншої людини, готовність жертвувати власними інтересами задля блага іншого, не пов'язана 3 власними егоїстичними інтересами (Н. Айзенберг, С. Майерс, Р. Немов та ін.).В Українському педагогічному словнику С. Гончаренка (1997) поняття альтруїзм ( dpp. altruisme від лат. alter інший) тлумачиться як «етичний принщип, що полягае в безкорисливому прагненні до діяльності на благо інших, у готовності заради іншої людини зректися власних інтересів» (Гончаренко С., 1997).

Виховання альтруїстичних якостей, що грунтуються на національних традиціях та демократичних засадах стало предметом дослідження українських педагогів-гуманістів та філософів минулого - Є. Гізеля, Г. Ващенка, І. Огієнка, С. Русової, В. Сухомлинського, Г. Сковороди, К. Ушинського, Т. Шевченка, Я. Чепіги, П. Юркевича та інших. Питання виховання альтруїстичної особистості цікавить також і педагогів сучасності - Т. Алексєенко, Л. Бабенко, I. Багмет, I. Беха, О. Вишневського, О. Срмакова, I. Магнутову, Ж. Омельченко, О. Пархоменко, О. Столяренко, О. Сухомлинську та ін. Незважаючи на те, що термін був запропонований у першій половині XIX ст., френомен альтруїзму як морально-етичного принципу у фрілософрських, психологічних, педагогічних дослідженнях ми спостерігаємо значно раніше. Проте, доцільно зазначити, що категорія альтруїзм ще не достатньо вивчена та досліджена через призму педагогічної думки та науки України. Чимало досліджень історичних надбань потребують глибокого аналізу та систематизації.

Як і багато інших педагогічних категорій, вивчення поняття альтруїзму його першопричини, генезису та місця в спадщині української та світової педагогіки, доцільно розпочати з основ, покладених ще у дохристиянський період, що служать своєрідним фундаментом усього філософського та педагогічного знання, витоки котрого сягають античних часів. Важливе місце в 
історії педагогічної думки посідае афрінська система виховання, котра, на відміну від спартанської системи, що зосереджувалася на фізичному розвитку, була спрямована на формування гармонійної особистості - високоморальної, духовно, творчо та фізично розвиненої. Видатним філософом, автором багатьох педагогічних ідей того часу був Сократ, метою виховання для якого було вдосконалення людиною власної моралі. Як моральний принцип у вченнях та поглядах Сократа розглядався і альтруїзм: «Не брати, а віддавати - суть морального закону, що урівноважуе егоїстичну волю кожної людини. I чим духовніша і душевніше людина, тим сильніше в ній бажання віддавати і служити людям» (Подольская Є., 2010). Всебічний розвиток та моральне виховання стало ідеологією мислителів того часу - Платона, Аристотеля, Демокріта, Ціцерона, Сенеки, Плутарха. Після завоювання Афін Римською Імперією М. Квінтіліан відстоював твердження стосовно вчителя, котрий має любити дітей, бути освіченим, прикладом для наслідування. Дослідженнями філософрьких вчень періоду античності, свого часу займалися i провідні українські мислителі - Ф. Прокопович, С. Яворський, І. Вишенський, Г. Сковорода та ін.

Етапи становлення східнослов'янської державності розглядають у двох періодах дохристиянський та християнський. Для культури дохристиянського періоду характерна усна народна творчість, сказання про моральні ідеали, проте, саме світосприйняття язичницьких слов'ян стало основою до входження самого християнства. Беручи до уваги традиції української педагогічної думки, можна зауважити, що неабияке значення в процесі iї формування i становлення належить дослідженню Святого Письма, впливу християнства, а також прийняття його законів як ффундаментальних та основних у системі виховання. Особливе місце у християнських вченнях належить явищу альтруїзму («Полюби ближнього як самого себе», «...більше ціеї любови ніхто не має, як хто душу свою покладае за друзів своїх»). Отець і Глава УГКЦ Блаженніший Святослав зазначае, що «справжній альтруїзм допомагае бути собою кожному із нас; альтруїзм - це спосіб життя» (Шевчук С., 2018).

Звертаючись до перших пам'яток давньоруської культури («Повість временних літ», «Слово о полку Ігоревім», «Повчання дітям») бачимо актуальними проблеми морального та релігійного виховання, потреби любові до людей, гуманності, безкорисливому служінні Батьківщині, правдивість та чесність.

На зміну рабовласницькому суспільству, зосередженого у найбільших державах Древньої Греції і стародавнього Риму, прийшла нова епоха - середньовіччя, період феодального суспільства, що характеризуеться монополізацією науки, мистецтва та освіти релігією та церквою, котрі заборонили культурну спадщину античного світу, а вивчення античних дисциплін («сім вільних мистецтв») було спрямовано виключно на засвоення та тлумачення церковних вчень і Святого Письма. Проте, на межі XI-XII ст., коли церковні школи, де найвищим рівнем освіченості було богослов'я, перестали задовольняти потреби швидко розбудованих міст, з'явилися нові типи шкіл (підтримувалися приватними особами), що стали доступними широкому загалу, а також університети, де учні оволодівали майстерністю навчати. Загалом, епоха середньовіччя відзначилася великим релігійним піднесенням. Саме в цей період з'явилося багато теологічних творів, серед яких «Наслідування Христа» Томи Кемпійського займае особливе місце. Цей твір можна сміливо назвати бестселером, адже за кількістю перекладів різними мовами світу, поступаеться лише Біблії. Трактат «Наслідування Христа» зробив неабиякий вплив на становлення та формування української фрілософської та педагогічної думки. У XVII ст. Є. Гізель, протестантський богослов, лідер соцініанського руху в Україні, ректор Киселинської школи переклав книгу грецькою мовою. Латинський текст використовували професори КиевоМогилянської академії, учні вищого граматичного класу Московської слов'яно-греко-латинської академії. Особливе місце займала книга в особистих бібліотеках Є. Гізеля, Ф. Прокоповича, С. Яворського, У. Нестурела, С. Гамалії, Г. Сковороди, М. Гоголя, М. Гулака, М. Костомарова, Т. Шевченка, I. Франка, I. Вагилевича та ін. Неабиякий вплив здійснила кордоцентричність Томи Кемпійського на формування української філософської та педагогічної думки. Поряд із цим можна зазначити, що своє відображення у трактаті займають і погляди на альтруїстичні вчинки і мораль християнина: «Ні за які скарби світу, ані для чиеї вподоби не годиться робити щось зле; але не раз треба навіть добру справу залишити, чи замінити на кращу, задля добра і потреби ближнього» (Кемпійський Т., 2014). Не дивлячись на те, що автор книги був католиком, присвятив усе життя вивченню Біблії та християнства, його праця має беззаперечне визнання з боку всіх провідних конфесій і церков світу.

У період XIV-XVI ст. українська система освіти і виховання формувалася в умовах фреодальної роздробленості та перебування південно-західних земель у складі Польщі, Литви, Угорщини і Молдавії. Церковні школи були единими закладами освіти, що виховували учнів у релігійному та частковому національному баченнях. У другій половині свою освітню діяльність здійснювали братські школи, які діяли у Львові, Острозі, Галичі, Луцьку, Вінниці, Кременці та в інших містах. 
Статути, що були основою у навчально-виховній діяльності братських шкіл, встановлювали серед своїх педагогів «навчати й любити всіх дітей однаково, як синів багатих, так і сиріт убогих і тих, котрі ходять по вулицях, просячи милостиню» (Кравець В., 1994).

Постійний тиск зі сторони католицизму зумовив занепад деяких культурних осередків на західній Україні і призвів до створення нових культурно-освітніх центрів у Києві. Важливий внесок у розвиток освіти зробила Київська братська школа, що пропагувала серед учнів виконувати обов'язки перед Богом, батьками, наставниками, виховання взаємної любові та самоповаги. Значну роль у становленні української освіти відіграла діяльність П. Могили засновника Київської колегії (Киево-Могилянської академії), котра стала освітнім культурнопросвітницьким центром не лише України, але й Білорусії, Молдови, Сербії, Росії. Серед випускників Києво-Могилянської академії - гетьмани Ю. Хмельниченко, І. Самойлович, П. Орлик, П. Полуботок; філософи - Є. Гізель, Л. Баранович, Г. Сковорода; письменники та вчені С. Гамалія, В. Рубан та ін.

Значиме місце в історії формування педагогічної думки займає епоха Відродження (XVIXVII ст.), що повернулась до античного ідеалу гармонійно розвиненої особистості, проте не відмовилась від релігійних поглядів в навчально-виховному процесі. З'явилась ідейна течія гуманізму, що характеризуеться культом людини, поваги до неї та вдосконалення її здібностей. Найвидатнішими представниками є Вітторіно де Фельтре (засновник школи «Будинок радості»), Ф. Рабле, Е. Роттердамський, М. Монтень, котрий вважав, що моральність для вчителя має бути важливішою за знання. У середині XVII ст. відбулося переосмислення та трансформація середньовічних поглядів на сощіальне та духовне життя, а також педагогічних ідей. Визначне місце та вплив на українську педагогіку мають дослідження та праці Я. А. Коменського. Видатний чеський педагог, суспільний діяч, філософ, основоположник філософії нового часу особливу увагу звертає на ідеї виховання особистості, виховання людяності в людини. В основі вчення «Правила поведінки» автор виділяе чотири основних доброчесності: мудрість, поміркованість, мужність і справедливість, звертає увагу на те, що моральні якості виховуються протягом усього життя, вони не є вродженими. Одним із яскравих представників епохи є англійський філософр, педагог Д. Локк, котрий вважав, що кожна дитина наче «чиста дошка» і лише внаслідок виховання вона отримуе добрі чи погані якості характеру. Послідовником Д. Локка вважається фрранцузький просвітитель Ж.-Ж. Руссо. У своєму творі «Еміль або про виховання» автор виділяе три завдання морального виховання: виховання добрих почуттів, добрих суджень і доброї волі. Педагогічні погляди Ж.Ж. Руссо про виховання «вільної людини», демократизм та патріотизм мали значний вплив на подальше становлення педагогічної думки. Ще один представник епохи Й.-Г. Песталощші зосереджував свою увагу на «гармонійному розвитку сил і здібностей людини». Рушійною силою виховання для нього е формування любові до людей, багато працював у галузі методики початкового навчання та виховання: «Мое серце торкалося сердець дітей, щоб їх щастя було моїм щастям, щоб моя радість була їх радістю». Й.-Г. Песталощщі увійшов у історію педагогіки як великий альтруїст, його діяльність зосереджувалась повною мірою на любові до дітей і всіх людей. На пам'ятнику видатному педагогу викарбувані слова «Все для інших, нічого для себе» - $e$ найкращою характеристикою його діяльності. Великий внесок у розвиток педагогіки зробив А. Дістервег - «учитель німецьких учителів», гуманіст, філософ, послідовник педагогічних ідей Й.Г. Песталощі, Лессінга. Метою та головним завданням виховання дітей і молоді, А. Дістервег вважав виховання любові до всього людства і до свого народу, розвиток «самодіяльності в служінні істині, красоті і добру». Ключова роль, на його думку, належить учителю, котрий повинен спрямовувати учнів до добра, істини.

У другій половині XV-XVI ст. в Україні сформувалося видатне явище в европейській історії козацтво. Козацька педагогіка орієнтувалася на формування національної свідомості та вірності Батьківщині. В цей період активно працювали академії, братські, дяківські, церковні школи, школи ремесел, січові козацькі школи. Особливе місце у козацькій педагогіці належить вихованню побратимства, честі, взаємодопомоги, самодисципліни, моральним та естетичним якостям. Освітній вплив козацької педагогіки протягом двох століть був припинений у 1775 р. Катериною II разом із зруйнуванням Запорізької Січі.

Як моральний принцип альтруїзм розглядався у XVIII ст. в працях і дослідженнях представників англійської етики - А. Шефттсбері, Ф. Хатчесон, А. Сміт, Д. Юм, фрранцузького Просвітництва - Ж.-Ж. Руссо, в німецькій етиці - Г. Лейбніц, І. Кант, Л. Фейербах. Філантропічнореформаторською можна вважати діяльність англійського педагога Р. Оуена, котрий розглядав альтруїзм обов'язковою умовою формування характеру в ранньому віці.

Вагомий внесок у розвиток філософрської думки та освіти зробив видатний просвітительгуманіст «український Сократ» Г. Сковорода. Принщип гуманізму, активно розвинений представниками епохи Відродження, Г. Сковорода трактуе як розуміння вихователями думок, 
переживань та прагнень дитини, віру у благородне особистісне начало та в силу виховання. Мислитель розглядає самобутність та особливість народу: «Правильне виховання криється в природі самого народу, як вогонь і світло криеться в кремені» (Ушкалов Л., 2017). Успішне виховання залежить від мотивації моральної поведінки, поваги і любові до дітей. Г. Сковорода є основоположником духовно-фрілософрської доктрини кордоцентризму, що розвиває етико-моральне вчення про людину, її щастя та шляхи його досягнення, про благо, добро і зло, сенс життя. Досягти щастя можливо лише у праці за покликанням: «роби те, до чого вроджений». Моральність людини, за Г. Сковородою, відображається у їі совісті, а моральні чесноти виростають, насамперед, з любові до інших людей, а також праці, яка дає їм користь. Письменник і фрілософр-мораліст Л. Толстой, прочитавши видання творів Г. Сковороди, зазначає: «Сковорода вчив, що святість життя - тільки в справах добра». Звернення до альтруїзму та добра у людині, їі здатність до здійснення альтруїстичних вчинків пропагуе у своїй творчості геній українського народу. Т. Шевченко.

В першій половині XIX століття, автор фрілософії позитивізму О. Конт запропонував термін «альтруїзм» 3 метою вираження поняття, протилежного егоїзму. Як принцип фрілософрії, за О. Контом, альтруїзм трактуеться як «Живи для інших». У XIX столітті під впливом утилітаризму розглядався як обмеження власних інтересів заради інтересів іншого. Пропагував у своїй діяльності виховання альтруїстичних почуттів і фрранцузький педагог С. Френе. Мета виховання, на його думку, полягає у «максимальному розвитку особистості в правильно організованому суспільстві, яке буде служити для неї і для якого буде служити вона» (Дичківська I., 2004).

На рубежі XIX-XX ст. науково-технічний прогрес, невідповідність школи вимогам та потребам часу, а також накопичення фрілосодських та психолого-педагогічних знань призвели до появи нових підходів, концепцій у галузях навчання та виховання. Сукупність усіх цих течій одержали назву редорматорської педагогіки, що акцентувала свою увагу на особистості дитини (А. Біже, Д. Дьюї, О. Декралі, Е. Клапаред, А. Фер’ер, Е. Вебер, Г. Гаудіг, Ф. Гансберг,Я. Корчак, Е. Лінде, М. Монтессорі та ін. ).

У Галичині у кінці XIX - на початку XX століття навчально-виховний процес здійснювався в режимі тогочасної політичної ситуації - виховання у молодого привілейованого покоління почуття зверхності до простого народу. Проте, на противагу панівному режиму, активну діяльність розгорнули громадські організації та педагогічні просвітницькі товариства. Їх освітня діяльність спрямовувалася на виховання патріотичної молоді, свідомої, культурної, освіченої, високоморальної («Сокіл», «Січ», «Пласт», «Молода Просвіта»).

Одним із фундаторів української національної педагогічної думки кінця XIX - початку XX ст. $є$ Г. Ващенко. У своїй книзі «Виховний ідеал», автор зосереджує увагу на аналізі окремих аспектів розвитку української духовності хронологічно від найдавніших часів до середини ХХ ст., розглядає становлення українського ідеалу виховання під впливом християнського, загальноевропейського, більшовицького та націонал-соціалістичного ідеалів виховання. Педагог підкреслює значимість наслідування власній національній самобутності, де головна життева мета української молоді служба Богові й Батьківщині через формування ідеалістично-релігійного світогляду, мужності, чесності, альтруїзму та солідарності, високої безкомпромісної принциповості. Звернення до альтруїстичних якостей особистості присутне у Г. Ващенка і у праці «Виховання волі і характеру». Педагог характеризує риси поведінки, притаманні альтруїстам, розглядає різні форми альтруїзму, а також значення альтруїзму у педагогічній та науковій діяльності - «Коли мова йде про альтруїстичний характер, ми мусимо мати на увазі усвідомлене служіння суспільству, що стало основною метою життя даної людини». Загалом, педагогічні ідеї Г. Ващенка можна вважати фрундаментальними у розбудові національної системи освіти, спрямовані на формування притаманного для українського народу християнського виховного ідеалу, розвиток морально, ідейно й фрізично здорового молодого покоління.

ХХ століття ввійшло в світову культуру не лише як період соціальних потрясінь, світових воєн, револющій, але й як період становлення культурних цінностей, гуманістичних ідеалів та установок, побудованих на досвіді попередніх століть, альтруїстичних вчинків. Розвиток педагогічної думки у XX ст. продовжувався на теренах редорматорської педагогіки.

Гуманістична виховна система видатного українського педагога В. Сухомлинського є однією із визначних та відомих у всьому світі. Відповідно до гуманістичних засад свого вчення, педагог наголошував на любові вчителя до дітей та здатності до виховання: «Що було найголовніше у моєму житті? Без вагань відповідаю: любов до дітей» (Сухомлинський В., 1972). В. Сухомлинський $є$ послідовником фрілософії кордоцентризму Г. Сковороди, що відображається у його працях - Серце віддаю дітям», «Народження громадянина», «Педагогіка серця», «Як любити дітей» та ін. Особливе місце у педагогічних поглядах В. Сухомлинського належить фрормуванню людяності, котру він розглядає як здатність до альтруїзму. Найдорожчим людським багатством він називав щастя творення радості для людей, наголошував, що виховання грунтується на народній педагогіці та 
загальнолюдських цінностях - добро,совість, честь, обов'язок, гідність. Вчитель, за переконанням В. Сухомлинського, повинен бути людинознавцем, котрому притаманні глибока любов до дітей, уміння виховувати в них доброту, людяність, сердечність, готовність прийти на допомогу, почуття власної гідності. Актуальними у будь-який час залишаються слова В. Сухомлинського: «...жити серед людей і для людей означає бачити себе очима громадянина, уміти оцінити себе з точки зору інтересів суспільства» (Сухомлинський В.,1972).

Я. Чепіга - український педагог, громадський діяч, автор понад 150 наукових праць 3 теорії та методики початкового навчання, ідеї якого вплинули на подальший розвиток педагогічної науки в Україні у 1920-30-их pp. XX ст., також звертався до категорії альтруїзму. Так, особливе місце у його поглядах займае проблема любові. Педагог розглядае любов до дитини як почуття ідейне та чисте, що «криеться глибоко в природі людини». «Любов примушуе нас думати про інших, дбати про їх добро і вносити в їхне життя спокій душевний. I ми, виконуючи поставлене завдання, здобуваємо й собі щастя: розвиваючи навколо себе добро, радість і приемність, ми відчуваємо їх у собі» (Чепіга Я., 1914). Я. Чепіга розглядае альтруїзм як загальнолюдську любов, котру можна розвинути у собі через систематичне самовиховання. В українській національній свідомості альтруїзм $е$ природженою якістю, проте умови соціального та економічного життя надають альтруїзму рис егоїзму. Перед вчителем стоїть завдання любити дітей і через свою любов навчити любити і їх: «Педагоги, навчіться любити дітей! Любов’ю до дитини ви хоч частково покриете тяжкий гріх байдужості громадянства і держави до морального виховання молодого покоління» (Чепіга Я., 1914).

Безумовно, видатною особистістю XX ст. е альтруїст, польський педагог і медик, керівник «Дому сиріт» Януш Корчак. Все свое життя він присвятив проблемі «загальнолюдському» вихованню дітей. «Педагогіка серця» Я. Корчака обгрунтовуе мету освіти і виховання - формування самобутньої, неповторної та вільної індивідуальності, це симбіоз християнської, прагматичної та гуманістичної педагогічних орієнтацій. Він визнає доцільність навчання відповідно до наступних принципів: «знання для знань», «наука для науки», «знання - до послуг людини, праця наша $\mathrm{i}$ сили - для ближніх» (Корчак Я., 2016) Виховання моральних якостей повинно відбуватися не лише через позитивні, але й негативні вчинки, котрі пробуджують «муки совісті». Важливо, щоб дитина сама відкривала красу та необхідність альтруїзму.

Своерідним різновидом гуманістичного, вільного виховання стала і концепщія італійського педагога М. Монтессорі.

$\mathrm{y}$ другій половині $\mathrm{XX}$ ст. філософсько-етична проблематика альтруїзму отримала розвиток у дослідженнях просоціальної поведінки; розглядається у контексті етики піклування (К. Гілліан, Н. Ноддінгс); еволюційної генетики, яка розглядала альтруїзм з точки зору особистих інтерсів (Р. Гріверс, Е. Уілсон). А Поддьяков диференціюе альтруїзм на два типи, перший із яких грунтуеться на гуманістичному спрямуванні особистості на допомогу іншим, а другий - передбачае, що суб'ект, ігноруючи власні інтереси, допомагае іншому, завдаючи шкоди його супротивникам. Власне цей тип вчений називае альтернативним альтруїзмом (Поддьяков А., 2007).

Обговорення / Discussion. Загалом, проблема альтруїзму в умовах сьогодення розглядається через призму психології, антропології, філософії. Певну увагу зарубіжних дослідників Дж. Броуді, Дж. Дарлі, Б. Латанеє, С. Шварца, а також вітчизняних - Т. Гавриливої, С. Занюк, М. Наконечної зосереджено на проблемі допомагаючи дій, також однією із пріоритетних е категорія емпатії С. Бетсон, Дж. Браун, Х. Хекхаузен, Ж. Маценко, М. Чепа та ін. Науковці сучасності Е. Єрмакова, I. Магнутова, Г. Міронова досліджують альтруїзм з точки зору його дуалізму - вроджені задатки до альтруїстичної поведінки повинні реалізовуватися в процесі виховання та самовиховання. I. Багмет, I. Магнутова та ін. розглядають альтруїзм як основу для формування гуманізму, щедрості, безкорисливості, емпатії, виявів співчуття та співпережиття. Є. Насиновська зазначає, що альтруїстична поведінка проявляеться у відношенні до певного соціуму, членом котрого $e$ індивід, так і за межами угрупувань. В сучасних емпіричних соціологічних та соціальнопсихологічних дослідженнях альтруїзм розглядається як критерій моральної поведінки (Дж. Райт) і як вищий етап морального розвитку особистості (Л. Кольберг, Т. Лайкона). Террі Хейк, один із сучасних провідних фахівців в галузі освіти у США, у своїй статті «Що потрібно для інновацій в освіті?» вказуе на альтруїзм як складову та один із факторів творення інновацій: «... щоб зробити щось від початку до кінця самотужки, потрібно бути генієм або, щонайменше, надзвичайно кмітливим. Хочеш іти швидко - йди сам; хочеш іти далеко - йди з кимось. Коли ви служите високій меті та не даєте егоїзму втручатися у ваші справи, то шанси створити справжню інновацію зростають» (Terry Heick, 2013). Протягом останніх десятиліть науковці I. Багмет, А. Моісеєва, Є. Насиновська, I. Стецько та ін. досліджують проблему альтруїстичної поведінки, їі мотивів та наслідків, проте дослідження альтруїзму в рецепції педагогів залишаться ще мало вивченим. 
Висновки / Conclusions. В умовах трансформації освітнього простору, соціокультурних процесів, що відбуваються в Україні, й водночас зростання певної байдужості, а також деякою мірою i егоїзму, зумовлюють необхідність розвитку фрахівця, спроможного до здійснення безкорисливої професійної діяльності на благо інших - до альтруїзму. Одним із завдань, покладених в основу вище зазначених документів, можна відзначити також вимогу виховання альтруїзму як складової частини гуманістично спрямованої, всебічно та гармонійно розвиненої особистості, адже саме в феномені альтруїзму закладена готовність людини піклуватися про потреби інших заради їх блага, любов до людей, безкорислива допомога, здатність робити певні вчинки, не очікуючи ніякої матеріальної чи моральної користі для себе. Особливу увагу дослідників (Т. Гаврилова, Н. Кузьміна, Г. Михальченко, І. Юсупов та ін.) привертае питання емпатії як одніеї зі складових альтруїзму.

Утім, незважаючи на значну увагу дослідників до окремих аспектів проблеми альтруїзму, на сьогодні в педагогічній науці неповно розкрито історичний досвід вітчизняних педагогів у зазначеному напрямку. Актуальність дослідження зумовлена також відсутністю достатньої кількості використання найкращих історичних надбань, теоретико-методичних розробок, які б дозволили впровадження вітчизняного досвіду минулого в сучасну систему освіти.

Таким чином, альтруїзм - це система ціннісних оріентацій особистості, спрямована на задоволення потреб іншої людини, готовність до безкорисливої турботи про благо інших. Узагальнюючи вище сказане можна зазначити, що проблема альтруїзму е досліджуваною та актуальною у різних історичних епохах, розглядалася видатними педагогами минулого і потребуе глибокого вивчення та аналізу науковцями сучасності. У наш час, коли проблеми булінгу, відсутності у підростаючого покоління здатності до милосердя та співчуття починають бути буденними, питання альтруїзму та здатності до альтруїстичних вчинків постае як ніколи актуальним. Розвиток, зміни, трансформації та вдосконалення сучасної системи освіти, а також урізноманітнення підходів до здійснення навчально-виховної діяльності неможливі без дослідження концепцій, поглядів, ідей та педагогічних здобутків видатних постатей минулого. Персоніфіковане, системне вивчення національної педагогічної думки, аналіз та систематизація вітчизняної педагогічної спадщини спрямовані на збагачення історико-педагогічної науки з метою їх подальшого проектування на сучасність та майбутне.

\section{Список використаних джерел і літератури / References}

1. Гончаренко, С. (1997). Украӥнський педагогічний словник. Київ: Либідь / Honcharenko, S. (1997). Ukrainskyi pedahohichnyi slounyk [Ukrainian Pedagogical Dictionary]. Kyiv: Lybid [in Ukrainian].

2. Дичківська, I. М. (2004). Інноваційні педагогічні технологї̈. Київ: Академвидав / Dychkivska, I. M. (2004). Innovatsiini pedahohichni tekhnolohii [Innovative Pedagogical Technologies]. Kyiv: Akademvydav [in Ukrainian].

3. Ильин, Е. П. (2013). Психология помощи. Альтруизм, эгоизм, эмпатия. Санкт-Петербург. / Il'in, Е. P. (2013). Psixologiya pomoshhi. Al'ruizm, e'goizm, e'mpatiya [Psychology of Care. Altruism, Egoism, Empathy]. Sankt-Peterburg [in Russian].

4. Кемпійський, Т. (2014). Наслідування Христа. Львів: Свічадо / Kempiiskyi, Т. (2014). Nasliduvannia Khrysta [The Imitation of Christ]. Lviv: Svichado [in Ukrainian].

5. Корчак, Я. (2016). Як любити дитину. Харків: Клуб Сімейного Дозвілля / Korchak, Ya. (2016). Yak liubyty dytynu [How to Love a Child]. Kharkiv: Klub Simeinoho Dozvillia [in Ukrainian].

6. Кравець, В. П. (1994). Історія украӥнської школи і педагогіки. Курс лекцій. Тернопіль: Тернопіль / Kravets, V. P. (1994). Istoriia ukrainskoi shkoly i pedahohiky. Kurs lektsii [The History of the Ukrainian School and Pedagogy. The Lectures Course]. Ternopil: Ternopil [in Ukrainian].

7. Поддьяков, А. Н.(2007). Альтер-альтруизм. Психология, 3, 98-107. / Podd'yakov, A. N. (2007). Al'teral'truizm [Alter Altruism]. Psixologiya, 3, 98-107 [in Russian].

8. Подольская, Е. А. (2010). Этика: кредитно-модульныцй курс. Москва: Издательско-торговая корпорация «Дашков и Ко» / Podol'skaya, Е. А. (2010). E'tika: kreditno-modul'nyj kurs [Ethics: credit modular rate]. Moscow: Izdatel'sko-torgovaya korporaciya «Dashkov i Ko» [in Russian].

9. Сухомлинський, В. О. (1972). Серце віддаю дітял. Київ: Радянська школа / Sukhomlynskyi, V. О. (1972). Sertse viddaiu ditiam [I Give My Heart to The Children]. Kyiv: Radianska shkola [in Ukrainian].

10. Ткаченко, Р. (2018). «Християни вірять у Бога-альтруїста», Глава УГКЦ про альтруїзм як спосіб життя християн. Інфбормаційний ресурс Украйнської Греко-Католицької Церкви. Взято з http://news.ugcc.ua/articles/hristiyani_viryat_v_boga_altruista_glava_ugkts_pro_altruizm_yak_sposib_zhittya_hri stiyan_81602.html (дата звернення 21.01.2018) / Tkachenko, R. (2018). "Khrystyiany viriat u Boha-altruista», Hlava UHKTs pro altruizm yak sposib zhyttia khrystyian ["Christians believe in God-altruist", Head of the UGCC on altruism as a way of life for Christians.]. Informatsiinyi resurs Ukrainskoi Hreko-Katolytskoi Tserkvy. Retrived from

http://news.ugcc.ua/articles/hristiyani_viryat_v_boga_altruista_glava_ugkts_pro_altruizm_yak_sposib_zhittya_hri stiyan_81602.html (last accessed 21.01.2018) [in Ukrainian]. 
11. Ушинський, К. Д. (2005). Про народність у громадському вихованні. Вибрані праці (Кн. 1, с. 127). Москва / Ushynskyi, K. D. (2005). Pro narodnist u hromadskomu vykhovanni [About the Society in Public Education]. Vybrani pratsi (Kn. 1, s. 127). Moskva [in Ukrainian].

12. Ушкалов, Л. (2017). Ловитва невловного птаха: життя Григорія Сковороди. Київ: Дух і літера / Ushkalov, L. (2017). Lovytva nevlovnoho ptakha: zhyttia Hryhoriia Skovorody [The catch of an unprotected bird: the life of Gregory Skovoroda]. Kyiv: Dukh i litera [in Ukrainian].

13. Чепіга, Я. Ф. (1914). Саловиховання вчителя. Київ: Українська педагогічна бібліотека / Chepiha, Ya. F. (1914). Samovykhovannia vchytelia [Teachers Self-Education]. Kyiv: Ukrainska pedahohichna biblioteka [in Ukrainian].

14. Эфроимсон, В. П. (1971). Родословная альтруизма. Новый мир, 10, 153 / E’froimson, V. P. (1971). Rodoslovnaya al'truizma [Pedigree altruism]. Novyj mir, 10, 153 [in Russian].

15. Skinner, Burrhus. (1953) Science and Human Behaviour. New York: Macmillan.

16. Heick, Terry. (2013). What You Need to Be an Innovative Educator. Eedutopia. Retrieved from https://www.edutopia.org/blog/what-you-need-innovative-educator-terry-heick (last accessed 30.07.2013).

Дата надходження статті: «10» жовтня 2018 р.

Стаття прийнята до друку: «15» листопада 2018 р.

Стойко Катерина - аспірант Тернопільського національного педагогічного університету імені Володимира Гнатюка

Stoiko Kateryna - postgraduate student of Ternopil Volodymyr Hnatiuk National Pedagogical University

Цитуйте ию статтю як:

Стойко, К. (2018). Проблема альтруїзму в світовій та українській педагогіці: історичний Педагогічний дискурс, 25, 42-49.
Cite this article as:

Stoiko, K. (2018). The Problem of Altruism in the World and Ukrainian Pedagogy: the Historical Aspect. Pedagogical Discourse, 25, 42-49. 